\title{
Study of Seasonality Tourism in Simanindo Sub- district, Samosir Regency
}

\author{
Dwi Debora Sitanggang ${ }^{*}$ \\ ${ }^{I}$ Departement of Interior Designer, Faculty of Art and Design, Sebelas Maret University, Surakarta, \\ Indonesia.
}

\begin{abstract}
Seasonal tourism is a phenomenon characterized by a determinative influence on the tourism industry. This phenomenon is not easy to solve or modify because it has related to tourist arrivals. The number of tourist arrivals is an important point because this is a source of income and revenue for the tourism industry. This study aims to understand and identify seasonal tourism that often occurs every year. The components or variables in this research measure level of tourist visits and the efforts to increase tourist visits outside the season. This research uses quantitative methods and qualitative methods. The data collection are consisted of: qualitative methods with data collection from observations, interviews, and questionnaires and quantitative methods by collecting data from agencies, books, and literature studies. The results are the peak season in the Simanindo sub-district originates from the influence of holidays or religious celebrations. The low season of tourism is caused by weather factors and human disasters. The seasonal pattern for the last three years has the same pattern. The government needs to improve the facilities and creates alternative activities during the low tourist season. The questionnaire's results from tourists satisfied with the tourism industry, infrastructure, and employment services.
\end{abstract}

Keyword: seasonality, Simanindo sub-district, tourism, visitor monitoring

Received 8-1-2021 | Revised 19-1-2021 | Accepted 18-2-2021

\section{Introduction}

Indonesia is one of the countries that relies on tourism as a priority sector for development. This development sector includes the economy, employment, and infrastructure [1]. Simanindo subdistrict is also one of the areas that relies on tourism as a source of income. Simanindo Subdistrict has the potential and tourist attraction in the field of nature tourism and historicalcultural tourism. Nature tourism highlights the natural charm and beauty of Lake Toba \& historical-cultural tours highlight the social interactions and relationships of the Batak ethnic groups who still maintain the tradition [2]. These types of tourism make the Simanindo subdistrict being well known by domestic tourists and international tourists. However, the

\footnotetext{
*Corresponding author at: Sebelas Maret University, Jl. Ir Sutami No.36A, Surakarta City, 57126, Indonesia. 
development of tourism will certainly face several problems, especially seasonal. Seasonal tourism is a phenomenon characterized by a determinative influence on the tourism industry. This phenomenon is not easy to solve or modify because it is closely related to tourist arrivals [3]. Therefore, seasonal tourism is a key aspect of solving important problems in efforts to develop sustainable tourism. Thus, this study aims to understand and identify the seasonal tourism phenomenon that has frequently occurred in Simanindo sub-district over the past three years.

\section{Literature Review}

Tourism is an activity of a person or group that moves from one place to another for a short time or temporarily and carries out activities while staying at the destination aim to entertain themselves or take a break from busy activities [4]. According to Indonesian Law Number 10 of 2009 [5], tourism is a variety of tourism activities that have or get supported by facilities \& services provided by the community, business, government, and local governments. The facilities and services based on UNWTO [6] are the tourism industry, including visitor accommodation, foods, and beverage service activities (restaurant and cafe), tourist objects, and tourism services (bureau/agency services).

Seasonality tourism is a phenomenon of tourism that has been experienced in global markets. This phenomenon is characteristic of an imbalance in the form of the number of tourist arrivals, the amount of tourist expenditure incurred, the situation and condition of infrastructure and supporting road facilities, the cost of admission to attractions if the tourist attraction has access limits, and the labor factor in the tourism industry [7]. Seasonal tourism consists of two periods, such as peak season and the low season. Both periods are considered crucial issues for a region whose economy is heavily dependent on the tourism industry. From an economic perspective, seasonality obstructs the economy's cycle, insufficiency in providing wages to workers, and experiencing financial losses. Therefore, there is a need for action and support from the government, organizations, or certain parties to attract tourist arrivals [8].

The cause of the seasonal tourism phenomenon consists of two parts: natural and social or institutional events [9]. Natural events are associated with erratic temporal variations, some of which attribute to climatic and weather conditions based on tourist destination areas that vary throughout the year. Meanwhile, social or institutional causes are matters relating to social activities and policies of a country. Can be known such as public holidays, school holidays, and religious celebration days. For example, an area will experience a density of tourist arrivals in December because there is a Christmas celebration where the moment is also close to New Year Day [9]. 
The reason for seasonal tourism stated by Cannas consists of three factors: unpredictable weather factors, holiday days, and calendar effects resulting from religious celebrations, and changes in the position of the month each year [10]. Seasonal tourism also occurs due to the attraction and incentive factors that depend on tourism development. The attraction factor is in the form of climatic conditions and unexpected social events. While the driving factor comes from requests from certain parties, for example, regional tourism institutions, socio-cultural figures, entrepreneurs, or managers [11]. Apart from natural and social (institutional) events, the causes of seasonal tourism are human factors. The reason for seasonal tourism based on human factors is the behaviour and activities at a particular place or time of the year. Activities can be in the form of outreach activities, short-term trends, the existence of a soccer league, visiting conventions, and performances [12].

The implications for seasonal tourism have both positive and negative impacts. However, these implications tend to lead to negative sides because they will effects employment, economic, environmental, and socio-cultural benefits [13]. During the low tourist season, employment factors in Simanindo sub-district cause limit or reduce the number of workers due to reduced job vacancies. It could create open unemployment or seasonal unemployment. It will be inversely proportional to the peak season, the number of job vacancies to cope with and serve busy tourist arrivals [3]. The seasonal impact on the economy is to provide a net profit in and around the region. Unfortunately, seasonal tourism results in operational difficulties for the tourism industry in boosting its economic growth. On average, entrepreneurs experience losses to get their capital back and have a problem attracting investors [14]. The negative effect of seasonal impact on the environment can be known from the highest point of tourist arrivals in the peak tourist season. These results are uncontrolled visitor density, increased air pollution, traffic congestion, and high waste disposal. Meanwhile, the positive side of the seasonal impact on the environment can be effected outside the season. Tourists tend to be less crowded but their arrivals tend to increase steadily without experiencing disruption to infrastructure, transportation, and accommodation [15]. Meanwhile, seasonal to socio-cultural relates to the peak season of tourism according to their destination. Socio-cultural also has the effect of seasonal fluctuations on entrepreneurs or managers. This effect of the dramatic increase in tourist population will also impose on tourism infrastructure and services in the form of congestion, lack of parking space at tourist attractions, and indiscipline of tourists when visiting tourist attractions [16].

\section{Methods}

The methodology used in this research is using both qualitative and quantitative methods. The method will be get simplified with a descriptive analysis approach. The descriptive analysis approach is an analysis that explains from the collection of primary and secondary data by 
making a general conclusion or generalization [17]. The components of variables in this research are identifying the degree of seasonality obtained by the level of tourist visits and efforts to increase tourist visitors during the tourism season. The degree component in research used quantitative methods, by collecting data from related agencies. This method also is used for founding the improvement of efforts to increase tourist visits outside the tourism season. Then the methodological technique is also supported by qualitative methods, by distributing questionnaires to tourists and agencies. The questionnaire collected by 102 respondents aims to see the perception of tourism in the Simanindo sub-district. Interviewed with agency sources also aims to meet data needs, if they do not have physical documents available.

\section{$4 \quad$ Result and Discussion}

How to measure the degree of seasonality in the Simanindo sub-district can be known by pay attention to the growth rate of the arrival of domestic visitors and international visitors. Based on Figure 1, most tourist destinations in the Simanindo sub-district have come from domestic visitors. The number of tourist visits in the Samosir Regency in 2018 reached 378,649 visitors and it increased to 418,271 visitors in 2019 . The arrival of tourists got decreased to 384,253 visitors in 2020. Seasonal tourism in 2018, such as the peak season occurred in June and the low season occurred in October. The main reason why the peak season happened in 2018 is that it has Eid Celebration. Seasonal tourism in 2019, such as the peak season occurred in December because it has a Christmas celebration while the low season is in November. Meanwhile, the seasonal tourism phenomenon in 2020, namely the peak season did happen in December. However, the low season occurred during the COVID-19 lockdown period started from February to June. 


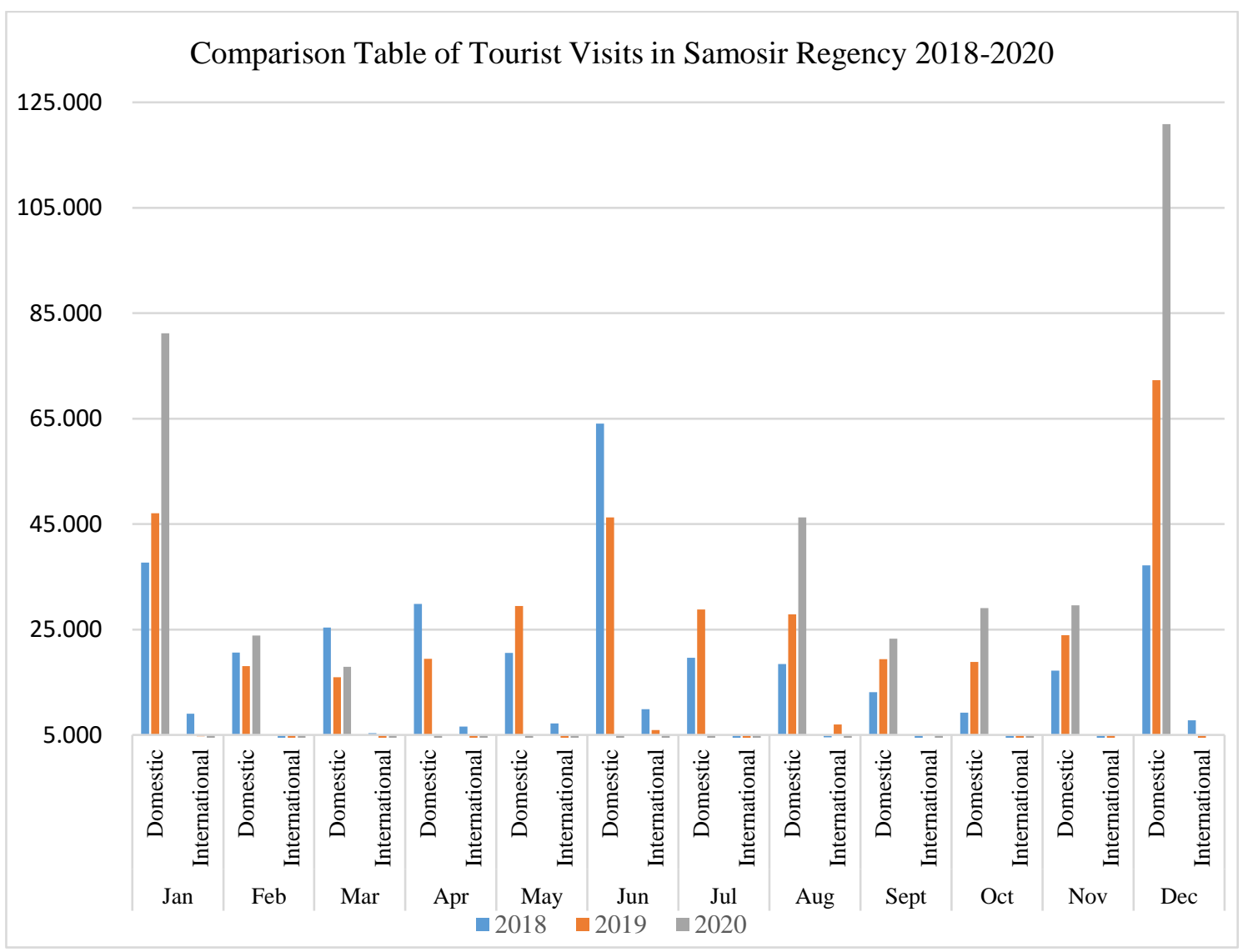

Figure 1 Comparison Table of Tourist Visits in Samosir Regency 2018-2020.

Based on Table 1, tourist arrivals in the peak season of June 2018 reached 70,023 tourists. The reason is the influence of the Eid celebration. Meanwhile, tourist arrivals in the low season of October 2018 only reached 13,522 tourists. Samosir Regency had the tragedy of the sinking of the Sinar Bangun Motor Ship which caused tourists not to travel for several months. Tourist arrivals in December 2019 reached 75,372 tourists, due to the influence of the Christmas celebration. Meanwhile, tourist arrivals during the low season in March reached 19,489 tourists. It happened because of the factor of heavy rainfall, the result makes some transportation accesses have suffered quite severe damage. Tourist arrivals in the peak season of December 2020 also have the same reason as 2019, the number of arrivals in that year is the highest if it compared to the last three years, reaching 120,885 tourists. Meanwhile, tourist arrivals in the low season during the COVID-19 lockdown period and November numbered no more than 4000 tourists.

Table 1 Monthly of Tourist Arrivals in Samosir Regency For Each Year

\begin{tabular}{ccccccc}
\hline Month & \multicolumn{3}{c}{ Domestic } & \multicolumn{3}{c}{ International } \\
\cline { 2 - 7 } & $\mathbf{2 0 1 8}$ & $\mathbf{2 0 1 9}$ & $\mathbf{2 0 2 0}$ & $\mathbf{2 0 1 8}$ & $\mathbf{2 0 1 9}$ & $\mathbf{2 0 2 0}$ \\
\hline January & 37.713 & 47.038 & 81.191 & 9.021 & 4.712 & 1.737 \\
February & 20.642 & 18.044 & 23.882 & 4.327 & 3.511 & 836 \\
March & 25.355 & 15.925 & 17.930 & 5.362 & 3.564 & 335 \\
April & 29.820 & 19.465 & 1.090 & 6.594 & 2.600 & -
\end{tabular}




\begin{tabular}{ccccccc}
\hline Month & \multicolumn{3}{c}{ Domestic } & \multicolumn{3}{c}{ International } \\
\cline { 2 - 7 } May & 20.548 & 29.437 & 2.172 & 7.168 & 4.435 & - \\
June & 64.074 & 46.286 & 2.104 & 9.912 & 5.949 & - \\
July & 19.625 & 28.796 & 3.924 & 4.055 & 4.346 & - \\
August & 18.480 & 27.891 & 46.262 & 4.517 & 6.989 & - \\
September & 13.101 & 19.355 & 23.267 & 2.407 & 5.122 & - \\
October & 9.212 & 18.852 & 29.052 & 1.433 & 4.310 & - \\
November & 17.198 & 23.893 & 29.586 & 3.135 & 2.379 & - \\
December & 37.157 & 72.319 & 120.885 & 7.793 & 3.053 & - \\
\hline Total & $\mathbf{3 1 2 . 9 2 5}$ & $\mathbf{3 6 7 . 3 0 1}$ & $\mathbf{3 8 1 . 3 4 5}$ & $\mathbf{6 5 . 7 2 4}$ & $\mathbf{5 0 . 9 7 0}$ & $\mathbf{2 . 9 0 8}$ \\
\hline
\end{tabular}

The room occupancy rate of Samosir Regency has generally decreased. In 2018, the room occupancy rate was $13.70 \%$, with a total of 2,077 rooms available. And then in 2019, the room occupancy rate got decreased to $13.20 \%$, with a total of 2,155 rooms available. Likewise in 2020 , the room occupancy rate decreased by $12.94 \%$ with the total number of rooms available only amounting to 2,035 rooms [18]. Based on observations, the Information Center facilities still do not meet the target. There is only one Information Center in the Simanindo sub-district, located in Tuk-Tuk Siadong. But the target number of Information Center facilities must reach five units as the target. The majority of visitors who visited the Information Center aim to obtain information on routine and alternative tourism activities, the state or condition of infrastructure along the roads and sub-district traffic, and sometimes visitors come to take tourism leaflets only. The tourists can access information from the tourism's call centre, and access the Department of Tourism's social media accounts or website.

Table 2 Tourist Visit Rate and Occupancy Every Month of the Year in Samosir Regency in 2020

\begin{tabular}{cccc}
\hline \multirow{2}{*}{ Month } & \multicolumn{2}{c}{ Tourist } & \multirow{2}{*}{ Occupancy (\%) } \\
\cline { 2 - 3 } & Domestic & International & \\
\hline January & 81.191 & 1.737 & $68,6 \%$ \\
February & 23.882 & 836 & $20,4 \%$ \\
March & 17.930 & 335 & $15,1 \%$ \\
April & 1.090 & - & $0,9 \%$ \\
May & 2.172 & - & $1,8 \%$ \\
June & 2.104 & - & $1,7 \%$ \\
July & 3.924 & - & $3,2 \%$ \\
August & 46.262 & - & $38,3 \%$ \\
September & 23.267 & - & $19,2 \%$ \\
October & 29.052 & - & $24,0 \%$ \\
November & 29.586 & - & $24,5 \%$ \\
December & 120.885 & 1.737 & $100,0 \%$ \\
\hline
\end{tabular}

\begin{tabular}{lll}
\hline Total & $\mathbf{3 8 4 . 2 5 3}$ & $\mathbf{2 6 \%}$ \\
\hline
\end{tabular}

Table 2 shows the highest occupancy of a tourist visit in December, reached $100 \%$. Next, January reached $68.6 \%$ and also in August with a percentage of $38.3 \%$. The phenomenon of these three months is part of the holiday season calendar that has contributed $68 \%$ of the total. 
Meanwhile, the low season point started from April to June. The lowest point of tourist arrivals was $0.9 \%$ in April, then $1.8 \%$ in May, and $1.7 \%$ in June. If the researcher compared it with the previous year's occupancy results, the occupancy rate in 2020 has decreased by $50 \%$. The efforts to increase the number of tourist visitors can be carried out by organizing several alternative activities outside of the routine tourism calendar implementation of the Department of Tourism. Department of Tourism also has an official local community named "Pokdarwis" that highly participates in these alternative activities. They have collaborated with some communities such as hobbies, sports, or nature care groups in Samosir Regency and its surroundings. "Pokdarwis" also involves the participation of local communities to develop the potential of tourism villages. Thus, all alternative activities created will get assisted by the Department of Tourism by promoting them on social media accounts and websites. Table 3 shows the number of alternative activities during the low tourist season in the Samosir Regency.

Table 3 Number of Events in the Low Tourism Season in Samosir Regency

\begin{tabular}{|c|c|c|c|c|c|c|c|c|c|c|}
\hline \multirow{3}{*}{ Year } & \multirow{2}{*}{\multicolumn{4}{|c|}{$\begin{array}{c}\text { Low Season } \\
1^{\text {st }} \text { Period }\end{array}$}} & \multirow{2}{*}{\multicolumn{5}{|c|}{$\begin{array}{c}\text { Low Season } \\
2^{\text {nd }} \text { Period }\end{array}$}} & \multirow{3}{*}{ Total } \\
\hline & & & & & & & & & & \\
\hline & Feb & Marc & Apr & May & Jul & Aug & Sept & Okt & Nov & \\
\hline 2018 & 1 & - & - & 1 & 2 & 1 & 2 & - & 1 & 8 \\
\hline 2019 & 1 & 1 & - & 1 & 4 & 2 & 3 & 2 & 1 & 12 \\
\hline 2020 & - & - & - & - & - & 2 & 1 & 1 & 1 & 5 \\
\hline
\end{tabular}

Source: MCSTO USU [19] and Department of Tourism

The researcher also distributed questionnaires aimed at tourists to twenty-one tourist destinations. The implementation of this questionnaire aims to obtain tourists of perceptions of seasonal tourism, namely regarding the reasons for tourists visiting outside the tourist season in the Simanindo sub-district. Concerning the questionnaire results, the researcher concluded that the tourists are dominant from local and around Samosir Regency. Most tourists agreed and feel satisfied with the tourist attraction, accessibility, infrastructure and support facilities, employment services in the tourist industry, and local foods. Tourists had fun experiences from tourist destinations. Some tourists did not complain about roads and signage along the Samosir sub-district. The reason is some tourists have already visited tourist destinations before. The tourists who visit for the first time at tourist destinations did complain, such as lack of road and signage, traffic lights, and parking. Most of the visitors had strongly satisfied with natural tourism and history-culture tourism in the Simanindo sub-district. They also like and agreed with the creativity of souvenirs that are sold around destinations. Some tourists can enjoy local foods. Local people did their best to make Muslim tourists has enjoyed the local foods by making the halal version. Tourists have an average opinion about employment service, 
especially in the hotel and food and beverage industry. They had experienced some employment does not work professional or slow response the visitors. Last, tourists strongly agreed if they will re-visit the tourist destinations.

\section{Conclusion}

In this paper, researchers have presented several methods for analyzing seasonal tourism in observing tourist arrivals. Analyze the seasonal in the Simanindo sub-district is an important tool for managing a tourism business and planning infrastructure and staff recruitment. Based on the theory, seasonal tourism in the Simanindo sub-district from 2018-2020 had highly influenced during the holiday. Thus, the government can predict the months that will count as low season months in 2021. The month prediction, which is part of the low season of tourism, will be filled with alternative activities that are more attractive and involve the local community and society. Based on the findings, the Department of Tourism can also re-evaluate programs for developing tourist destinations and tourist attractions to increase tourism demand in each village. This research can get improved by better sampling. This research should be useful for the Samosir Regency government.

\section{Acknowledgment}

The researchers would like to acknowledge the Department of Tourism and Porkdarwis for their generous assistance in this project. The author would also like to thank anonymous visitors and the tourism industry's employees for their valuable comments and suggestions for improving the quality of content.

\section{REFERENCES}

[1] Addin Maulana, dkk. "Seasonal Pattern of Foreign Tourist Arrivals to Bali". Jurnal Kepariwisataan Indonesia 14 (2) (2020). P-ISSN: 1907-9419E-ISSN: 2685 -907. 2020.

[2] Fransiska Roslila Eva Purnama Pardede \& Ida Agus Senayan. "MANAGEMENT STRATEGY OF SAMOSIR DISTRICT AS NATURAL TOURISM INTEREST IN NORTH SUMATERA PROVINCE”. Jurnal Destinasi Pariwisata Vol 04 No. 01 2016. ISSN: 2338-8811.2016

[3] R.W. Butler. "Seasonality in Tourism: Issues and Implications". In T. Baum, \& S.Lundtorp (Eds.), Seasonality in Tourism. Oxford: Elsevier Science. 2001.

[4] Christian Gideon Suot, dkk. "Pengaruh Sektor Pariwisata dan Pertumbuhan Ekonomi Terhadap Pendapat Asli Daerah di Kota Manado”. EMBA Journal, Vol 9 No. 12021. ISSN 2303-1174. DOI: https://doi.org/10.35794/emba.v9i1.32194. 2021.

[5] Tourism of the Republic of Indonesia, The Law of Indonesian Republic Number 10 of 2009. [Online]. https://jdih.kemenkeu.go.id/fullText/2009/10TAHUN2009UU.HTM

[6] UNWTO. "International Recommendations for Tourism Stastistics 2008”. 2010. 
[7] Daniel Chandrachur Annisius. "Managing Seasonality in Tourism: Challenges and Opportunities for the Tourism Industry in Húsavík, Iceland”. 2014.

[8] Simon Chiutsi and Boycen Kumira Mudzengi. "Tourism Seasonality and Destination Management Implications for Mana Pools Tourist Destination in Zimbabwe". African Journal of Hospitality, Tourism and Leisure, Volume 6 (2) -ISSN: 2223-814X. 2017.

[9] N. Koenig-Lewis and E.E. Bischoff. Developing Effective Strategies for Tackling. Seasonality in the Tourism Industry". Tourism and Hospitality Planning \& Development. 2010.

[10] R. Cannas. "An overview of tourism seasonality: Key Concepts and Policies". Almatourism-Journal of Tourism, Culture and Territorial Development. 2012.

[11] Coran Gorluka. “Tourism Seasonality. An Oveview.” Article of University of Split 2018. Croatia. [Online] Avaiable: Researchgate. 2019.

[12] Ahmad Alshuqaqi and Shida Irwana Omar. "Causes and Implication of Seasonality in Tourism”. Journal of Adv Research in Dynamical \& Control Systems, Vol. 11, 04-Special Issue, 2019. ISSN 1943-023X. 2019.

[13] Biljana Petrevska. INVESTIGATING TOURISM SEASONALITY IN MACEDONIA. UTMS Journal of Economics. Vol 4. 2013.

[14] Aleksandar Trajkov, Jovanka Biljan, amd Cyetko Andreeski. Overview and Characteristics of Tourism Seasonality in Ohrid. Economic Themes. 2016.

[15] Dilfuza, Khamzaeva. THE PROBLEM OF SEASONALITY IN TOURISM. Theoretical \& Applied Science. 91. 337-340.10.15863/TAS.2020.11.91.56. 2020.

[16] Sofia Gkarane and Christos Vassiliadis. Selective Key Studies in Seasonality Tourism: A Literature Review. [Online] Avaiable: Researchgate. 2019.

[17] Prof. Dr. Sugiyono. "Metode Penelitian. Kuantitatif, Kualititatif, dan R\&D”. Bandung; Penerbit Alfabeta. 2018.

[18] Badan Pusat Statistik. "Tingkat Kedatangan Wisatawan di Kabupaten Samosir". 2020. [Online]. https://samosirkab.bps.go.id/. 2020.

[19] MCSTO USU. "Sustainable Tourism Observatory Lake Toba”. 2019. 